\title{
Radiometric Survey as a Useful Tool in Geological Mapping of Western Nigeria
}

\author{
A. N. Amadi \\ Department of Geology, Federal University of Technology, Minna, Nigeria \\ Tel: 234-818-821-8076_E-mail: geoama76@gmail.com \\ N. O. Okoye, P. I. Olasehinde, I. A. Okunlola, Y. B. Alkali, T. A. Ako \& J. N. Chukwu \\ Department of Geology, Federal University of Technology, Minna, Nigeria
}

Received: December 26, $2011 \quad$ Accepted: January 9, 2012 Published: March 1, 2012

doi:10.5539/jgg.v4n1p242 URL: http://dx.doi.org/10.5539/jgg.v4n1p242

\begin{abstract}
Gamma ray Spectrometer (DISA-300) and broadband gamma ray scintillometer (BGS-ISL) were used to evaluate the radiometric properties of rocks (Igneous, Sedimentary and Metamorphic) in parts of southwestern Nigeria. The study revealed that although the two instruments used recorded different gamma radiation value and the graphs generated by the instruments are quite similar. Based on the major peaks and troughs of the radioactivity graph, the different formations in the area were clearly delineated and these correspond approximately to the geological boundaries in the area. Lithologic characterization of the formations revealed that the concentration of radioactive elements in rock varies. Shale, clay and granites have the highest amount of gamma count (60-105) while amphibolites show the lowest gamma count (16-46). The gamma count is a function of the concentration of radioactive elements in the rock. The reading ranges from $65-85 \mathrm{cps}$ in the scintillometer while the spectrometer varies from 19.75-38.88cps. The difference in readings may be attributed to the higher sensitivity of the scintillometer to gamma radiation than the spectrometer. However, the two instruments display similar pattern of curves and good correlation.
\end{abstract}

Keywords: Radiometric survey, Geological mapping, Gamma count, Western Nigeria

\section{Introduction}

Radioactivity is the spontaneous decay or disintegration of an unstable atomic nucleus usually accompanied by the emission of radiation (Heinrich, 1985). The major assignment of a structural geologist in the field is to delineate as correctly as possible the rock units existing in the field. Areas with deep weathering and thick overburden usually compound the problem of rock delineation. One of the ways to achieve greater accuracy in facies delineation is by the use of radiation (alpha- $\alpha$, beta- $\beta$ and gamma- - ) emanating from the decay of radioactive element contained in the rock unit. The most useful of these radiations in radiometric survey are gamma radiations. They are usually among the decay products of radioactive elements such as Uranium, Thorium and Potassium (K-40). Of all known radioactive elements, only those of Uranium, Thorium and Isotopes of Potassium (K-40) are of importance in geologic mapping and mineral exploration (Faure, 1977). The rest are either so rare or so weakly radioactive or both as to be of no significance in applied geology.

\subsection{Study Objectives}

The study is aimed at establishing the importance of gamma radiation emanating from radioactive elements contained in rock formations to geological mapping. This objective is seen to be valid because of the geological environment of the area. Apart from the sedimentary formations, most of the outcrops belonging to the crystalline basement rocks in the area are low-lying and deeply weathered. It is obvious that the conventional geological mapping of the area may only be subjective since there are little or no outcrops to map, and as a result, accurate mapping would depend on the experience and technical know-how of the geologist in the field. But, with the use of radiometric survey, the equipments would simply pick up the gamma rays from the radioactive elements in the various lithologies with or without outcrop. The survey was also meant to compare the peaks and troughs in the gamma rays in a particular profile with the already established lithologies from the geological map of the area. 


\section{Material and Methods}

\subsection{Study Area Description}

The study area lies on the western part of Nigeria between longitude $3^{\mathrm{O}} 00^{\mathrm{I}} \mathrm{E}$ and $6^{\mathrm{O}} 30^{\mathrm{I}} \mathrm{E}$ of the Greenwich meridian and latitude $6^{\circ} 30^{\circ} \mathrm{N}$ and $7^{\circ} 30^{\circ} \mathrm{N}$ of the equator (Figure 1). Within the area, traverses were made along Lagos-Ibadan expressway, covering a distance of $29 \mathrm{~km}$; Shagamu-Ijebuode road, covering a distance of $21 \mathrm{~km}$ and Oru-Ijebuode road covering a distance of $13 \mathrm{~km}$ (Figure 1). Readings were taken at an interval of $1 \mathrm{~km}$ in each of the traverses. The survey covered a total traverse distance of about $63 \mathrm{~km}$ taken primarily across the general trend of the rock formations in the area. The area has low-lying undulating planes broken at intervals by low-lying hills. The climatic conditions of the area fall into the sub-equatorial type with characteristic heavy rainfall, usually between the months of April and September. The dry season takes off from October and ends in March. The mean annual rainfall is between $150 \mathrm{~cm}$ and $187 \mathrm{~cm}$ while the mean annual relative humidity is over $80 \%$ and the mean annual temperature is greater than $21^{\circ} \mathrm{C}$ (Jones, 2002).

\subsection{Regional Geology and Stratigraphy of the Area}

The Dahomey Basin is an extensive sedimentary basin on the continental margin of the Gulf of Guinea. It runs parallel to the coastal margins of Ghana, Togo, Benin Republic and Southwestern Nigeria (Figure 1). It is separated from the Niger Delta basin by the Benin hinge line and the Okitipupa ridge (Adegoke, 1972, Bankole et.al., 2006). The basin is a marginal pull-part (Rayment, 1965) or marginal sag basin (Whiteman, 1982) which developed in the Mesozoic era when the African and South American plates separated and the continental margin was founded (Adeleye, 1972; Jones, 2002). The Benin hinge line is part of the chain oceanic fractures while the Okitipupa ridge is a submarine basement ridge (Adegoke, 1972; Fayose, 1970). It is underlain by the quaternary deposits of the Dahomey Basin (Adegoke and Omotsola, 1981). The area has not witnessed epirogenic movement and as a result the rocks are not folded nor faulted. The stratigraphic units are the coastal plain sand and quaternary alluvium deposits (Table 1).

\subsection{Instrumentation}

Gamma ray spectrometer model DISA-300 and Broadband gamma ray scintillometer BGS-ISL were the gamma radiation counting instruments used for this study. The BOS-ISL gamma-ray scintillometer is a highly portable, transistorized instrument used for locating gamma ray emitting material. The audio output circuit included gives an aural indication of the presence of radiation. This circuit complements the metre readout of the same radiation levels and does this by pitch change, proportional to the radiation level. A sound threshold allows for the adjustment of level above the background at which the sound is activated.

Similarly, the Gamma-Ray Spectrometer (Model DISA-300) has basically the same principles and builds up as the scintillometer described above. It transforms incident gamma ray radiations into visual read out of radioactive intensities, as a function of the natural gamma ray energy present in geological phenomena. The frequency or signal readout rats displayed is the intensity of all gamma ray energy above a selected threshold setting. The digital readout therefore is essentially a summation of integral measurement.

Traverses were made across the general trend of the lithologic units in the study area with a view to monitoring the changes in the gamma radiation values of these formations in order to delineate them accordingly. Readings of gamma radiations were taken at intervals of $1 \mathrm{~km} ; 4$ readings were taken at each location and the average values were used. Readings were computed and radioactivity graph plotted. In order to obtain accuracy readings, the following precautions were taken:

i) Readings were taken far away from electric power lines.

ii) Readings were taken far away from vehicles/cars.

iii) Reading were taken off tarred road.

iv) The equipments were held firm and at about $1.5 \mathrm{~m}$ above the ground level before taking readings.

\subsection{Radioactive Elements in Minerals and Rocks}

The origin of radioactive elements in rocks is linked directly with the crystallization of magma. Radioactive elements do not readily combine with silicate minerals in the melt; rather they are deposited by residual fluid of a magmatic upsurge (Jones, 2002). Variation in radioisotope concentration is a function of primary geologic processes such as mineralizing solutions and metamorphic gradients. Oxidation due to weathering produces mobility of radioactive elements in rocks (Langmuir, 1978). Primary mineralization of Uranium occurs in rocks as $\mathrm{U}^{4+}$. On decomposition, however, of these rocks, Uranium is converted $\mathrm{U}^{6+}$ (Jager and Hunziker, 1979). Oxidation due to weathering produces the highly mobile form of Uranium called Uranyl-sulphate $\left(\mathrm{UO}_{2} \mathrm{SO}_{4}\right)$. It 
may also be transported to rocks in form of hydrosalt and complex alkaline uranium carbonates. Potassium $(\mathrm{K}-40)$ is released from its rock source as K-salts under the joint action of water, carbondioxide and organic acids. All the mobile ions of the radioactive elements are trapped in various Lithologic units by ion-exchange processes and in proportion to the ion-exchange capacity of these units.

\section{Results}

The results of the traverse along Lagos-Ibadan Expressway, Shagamu-Ijebuode road and Ore-Ijebuode road are summarized in Tables 2, 3 and 4 respectively while their corresponding radioactivity graphs are contained in Figures 2, 3 and 4 respectively. The result of the geochemical analysis carried out on selected rock samples from the area during geological mapping confirm high concentration of $\mathrm{K}_{2} \mathrm{O}$ compared to $\left(\mathrm{Na}_{2} \mathrm{O}\right.$ and $\left.\mathrm{CaO}\right)$, which agrees with the gamma radiation counts exhibited by scintillometer and spectrometer due to its radioactive nature. The independent radioactivity graphs using scintillometer and spectrometer are very similar in the peaks and troughs. The troughs correspond to facies with low radioactive element content (low gamma radiation counts) as typified in amphibolites and hornblende gneiss while the peaks show high radioactive element content (high gamma radiation counts) are evidenced in such rocks as clay, shale and granites. Also, the troughs in the radioactivity graphs correspond to the geologic boundary in the geological map when superimposed. This is an indication that radiometric method might form a useful tool in geological mapping and in Lithologic characterization.

\section{Discussion of Results}

The gamma radiation readings were generally higher for scintillometer than those of spectrometer for the same location and this implies that scintillometer is a more sensitive than spectrometer in detecting radiations. The consistency in pattern of the radioactivity graphs for the same traverse using different radiometric equipments has proved the effectiveness and reliability of radiometric mapping in lithologic characterization. Detailed geological mapping was carried out in the area extensively in order to validate the efficacy of the radiometric survey. The presence of unconformity surface, fold axial plane or fault zone were not observed during the mapping exercise. Their absence in the area further confirmed that radiometric mapping as a good means of delineating rocks. The major peaks and trough observed in the radioactivity graphs have consistently reflected radioactive element content in different rock units from the area. These litho-facies changes in response to their geology have the potentials of either attracting or repelling radioactive elements. In the Ibadan-Lagos expressway traverse, the Ewekoro Formation which indicated the highest radioactive element content contains clay, limestone (known for trapping radioactive elements) and glauconite, which contains radioactive potassium (K-40) via litho-logs from the formation (Adegoke, 1972). Similarly, the Shagamu-Ijibuode traverse contains the Abeokuta Formation, which overlies uncomformably the Basement Complex. On the other hand, in the Oru-Ijebuode traverse, the rock unit containing amphibolite show a very low gamma radiation because amphiboles crystallize early in the Bowen's Reaction Series and as a result is devoid of radioactive element. Major metamorphic rocks mapped in the area are gneiss and schist.

The area of study has been mapped by professionally competent geologists and modified by Bankole et al., (2006). The present study is therefore necessary to correlate the peaks and troughs of the gamma radiation graph with already established geological map of the area produced by conventional geological mapping. Generally, radioactive elements (uranium, thorium and potassium-40) are enriched in the residual phases of magmatic differentiation which is associated with the formation of alkaline rocks. Ultramafic and mafic minerals, including all early differentiation (olivine, pyroxene and amphiboles) contain very low amount of radioactive minerals. The influence of metamorphism in these lithologies leads to remobilization and not reduction of the radioactive mineral content.

\section{Conclusion}

The similarity in the radioactive curves from the instruments used in delineating the different lithologies has given credence to the usefulness of radiometric mapping as an alternative to geologic mapping. The disparity in the actual gamma radiation values by the two instruments (Gamma ray spectrometer model DISA-300 and Broadband gamma ray scintillometer BGS-ISL) are reflections of their individual sensitivity. Geological sections of the traverse routes were in agreement with the radioactivity graphs generated. The Lithologic character of each rock unit is simply reflected by the amount of gamma radiation recorded. Lithologies like shale, clay and granites have exhibited high content of radioactive minerals unlike amphibolites. By this study, it has been established that radiometric mapping may provides an invaluable aid in geological mapping of terrains with poor exposures. Readings were taken at distance away from tarred road, electric power lines, and vehicles as these have the potentials to influence the gamma radiation results. 


\section{References}

Adegoke, O. S. \& Omatsola, M. E. (1981). Tectonic evolution and cretaceous stratigraph of the Dahomey basin. Journal of Mining and Geology, 18(1), 130-137.

Adegoke, O. S. (1972). Paleocene molluscus from Ewekoro Formation, Southwestern Nigeria. Proceedings, $4^{\text {th }}$ European Malsc. Congress, Geneve, 71p.

Adeleye, D. R. (1972). Stratigraphy and Sedimentation of the Upper Cretaceous strata around Bida, Nigeria. Ph.D thesis, University of Ibadan, Unpublished.

Bankole, S. I., Schram, E., Erdtmann, B. D. et al. (2006). Palynostratigraphic age and paleoenvironments of the newly exposed section of the Oshosun formation in the Sagamu Quarry, Dahomey basin S.W.Nigeria. NAPE Bulletin, 19(2), 25-27.

Faure, G. (1977). Principles of Isotope Geology. UK: John Willy and Sons Inc. 331p.

Fayose, E. A. (1970). Stratigraphical paleontology of Afowo I well. S. W. Niger. Journal of Mining and Geology, 5(1), 28-30.

Heinrich, E. W. (1985). Mineralogy and Geology of Radioactive raw materials. Toronto, London: Mcgraw Hill book coy. 654p.

Jagere, E. \& Hunziker, R. D. (1979). Isotope Geology. Heidelberg New York: Springer-Verlog Berlin. 329p. http://dx.doi.org/10.1007/978-3-642-67161-6

Jones, H. A. \& Hockey, R. D. (1964). The Geology of parts of Southwestern Nigeria. Bulletin Nigerian Geological Survey Agency, 31(1), 87-93.

Jones, 1. (2002). Shrinking and Swelling soil in the UK; assessing clays for the planning process in Earthwise magazine. A publication of British Geological Survey, 18, 22-23.

Langmuir, D. (1978). Uranium solution mineral equilibria at low temperatures with application to sedimentary Ore deposits in Kimberley. Short course in Uranium Deposits, their Mineralogy and Origin. Toronto Mineralogical Association, Canada, 17-55.

Reyment, R. A. (1965). Stratigraph of some borehole in western region of Nigeria. Journal of Mining and Geology, 2(1), 1-11.

Whiteman, A. (1982). Nigeria: its Petroleum Geology, Resources and Potential. London: Graham and Trotman Publishers, 301-310. http://dx.doi.org/10.1007/978-94-009-7361-9

Table1. Stratigraphic correlation of Dahomey Basin

\begin{tabular}{|l|l|l|}
\hline Age & Jones and Hockey (1964) & Adegoke and Omatsola (1981) \\
\hline Recent & $\begin{array}{l}\text { Alluvial Littoral Lagoonal } \\
\text { Deposit. }\end{array}$ & \\
\hline Miocene Oligocene & Coastal Plain Sand & Coastal Plain Sand \\
\hline Upper Euocene - Oligocene & Baro Formation & Ilaro Formation \\
\hline Lower Euocene - Middle Eocene & Oshosun Formation & Oshosun Formation \\
\hline Lower Eocene - Upper Paleocene & Akimbo Formation & Akimbo Formation \\
\hline Paleocene & Ewekoro Formation & Ewekoro Formation \\
\hline Mastrician & Araromi Formation & Araromi Formation \\
\hline Turonian & Afowo Formation & Afowo Formation \\
\hline Neocomian Albian & Ise Formation & Ise Formation \\
\hline Precambrian & Basement Complex & Basement Complex \\
\hline
\end{tabular}


Table 2. Gamma Radiation Readings in Counts per Second (cps); Traverse: Ibadan-Lagos Expressway (Interval Distance $=1 \mathrm{~km}$ )

\begin{tabular}{|c|c|c|c|c|c|c|c|c|}
\hline \multicolumn{3}{|c|}{ Scintillation counter (cps) } & \multicolumn{4}{|c|}{ Spectrometer (cps) } & \multirow[b]{2}{*}{ Av. count per-2sec } & \multirow[b]{2}{*}{$\begin{array}{l}\text { Av.count } \\
\text { per-sec }\end{array}$} \\
\hline Station No & Distance $(\mathrm{km})$ & Total count/sec(cps) & 1 & 2 & 3 & 4 & & \\
\hline 1 & 0 & 80 & 59 & 57 & 56 & 58 & 57.33 & 28.67 \\
\hline 2 & 1 & 85 & 60 & 58 & 51 & 54 & 55.75 & 27.88 \\
\hline 3 & 2 & 80 & 53 & 53 & 49 & 50 & 51.25 & 25.63 \\
\hline 4 & 3 & 65 & 47 & 53 & 54 & 46 & 50.10 & 25.00 \\
\hline 5 & 4 & 60 & 38 & 46 & 43 & 41 & 42.00 & 21.00 \\
\hline 6 & 5 & 65 & 37 & 44 & 56 & 53 & 47.50 & 23.75 \\
\hline 7 & 6 & 75 & 64 & 66 & 67 & 62 & 64.75 & 32.38 \\
\hline 8 & 7 & 60 & 53 & 51 & 58 & 49 & 52.75 & 26.38 \\
\hline 9 & 8 & 65 & 48 & 48 & 55 & 47 & 49.50 & 24.75 \\
\hline 10 & 9 & 65 & 45 & 51 & 53 & 56 & 51.25 & 25.63 \\
\hline 11 & 10 & 165 & 61 & 62 & 57 & 59 & 59.75 & 29.88 \\
\hline 12 & 11 & 70 & 35 & 42 & 45 & 36 & 39.50 & 19.75 \\
\hline 13 & 12 & 85 & 65 & 68 & 68 & 70 & 67.75 & 33.88 \\
\hline 14 & 13 & 80 & 70 & 69 & 70 & 66 & 68.75 & 34.38 \\
\hline 15 & 14 & 75 & 63 & 57 & 59 & 65 & 61.00 & 30.50 \\
\hline 16 & 15 & 90 & 51 & 59 & 57 & 52 & 54.75 & 27.38 \\
\hline 17 & 16 & 80 & 48 & 60 & 64 & 66 & 59.50 & 29.75 \\
\hline 18 & 17 & 90 & 67 & 71 & 66 & 64 & 67.00 & 33.50 \\
\hline 19 & 18 & 100 & 70 & 75 & 72 & 70 & 71.75 & 35.88 \\
\hline 20 & 19 & 100 & 79 & 76 & 80 & 76 & 77.75 & 38.88 \\
\hline 21 & 20 & 105 & 73 & 83 & 47 & 52 & 63.75 & 31.88 \\
\hline 22 & 21 & 90 & 55 & 53 & 56 & 69 & 58.25 & 29.38 \\
\hline 23 & 22 & 70 & 48 & 50 & 56 & 50 & 51.00 & 29.75 \\
\hline 24 & 23 & 80 & 52 & 60 & 60 & 63 & 58.75 & 25.50 \\
\hline 25 & 24 & 75 & 64 & 59 & 60 & 55 & 59.50 & 29.38 \\
\hline 26 & 25 & 80 & 55 & 53 & 52 & 47 & 51.75 & 29.75 \\
\hline 27 & 26 & 80 & 66 & 64 & 66 & 61 & 64.25 & 25.88 \\
\hline 28 & 27 & 70 & 55 & 49 & 66 & 60 & 57.50 & 32.75 \\
\hline 29 & 28 & 90 & 66 & 63 & 67 & 60 & 64.00 & 32.00 \\
\hline 30 & 29 & 90 & 24 & 65 & 57 & 58 & 58.50 & 26.25 \\
\hline
\end{tabular}

Cps $=$ Counts per Second; Av. $=$ Average; Background Count $=19.75 \mathrm{cps}$ 
Table 3. Gamma Radiation Reading in Counts per Second (cps); Traverse: Shagamu-Ijebuode road (Interval Distance $=1 \mathrm{~km}$ )

\begin{tabular}{|l|l|l|l|l|l|l|l|l|l|}
\hline \multicolumn{3}{|c|}{ Scintillation counter (cps) } & \multicolumn{3}{|c|}{ Spectrometer (cps) } & \\
\hline Station No. & $\begin{array}{l}\text { Distance } \\
(\mathrm{km})\end{array}$ & Total count/sec(cps) & 1 & 2 & 3 & 4 & Av.count per 2 sec & $\begin{array}{l}\text { Av.count } \\
\text { per-sec }\end{array}$ \\
\hline 1 & 0 & 60 & 44 & 47 & 52 & 47 & 47.50 & 23.75 \\
\hline 2 & 1 & 65 & 30 & 31 & 26 & 30 & 29.25 & 14.63 \\
\hline 3 & 2 & 70 & 48 & 56 & 43 & 43 & 49.50 & 23.75 \\
\hline 4 & 3 & 110 & 45 & 43 & 49 & 40 & 44.26 & 22.18 \\
\hline 5 & 4 & 100 & 64 & 66 & 61 & 63 & 63.50 & 31.75 \\
\hline 6 & 5 & 95 & 78 & 59 & 67 & 77 & 69.75 & 34.89 \\
\hline 7 & 6 & 110 & 70 & 63 & 69 & 65 & 66.75 & 33.36 \\
\hline 8 & 7 & 85 & 67 & 63 & 66 & 64 & 65.00 & 32.50 \\
\hline 9 & 8 & 100 & 61 & 55 & 66 & 60 & 60.50 & 30.25 \\
\hline 10 & 9 & 80 & 56 & 58 & 55 & 55 & 56.00 & 28.00 \\
\hline 11 & 10 & 70 & 47 & 48 & 52 & 43 & 47.50 & 23.75 \\
\hline 12 & 11 & 75 & 59 & 60 & 50 & 59 & 57.00 & 28.50 \\
\hline 13 & 12 & 80 & 68 & 54 & 58 & 61 & 59.00 & 29.50 \\
\hline 14 & 13 & 65 & 52 & 50 & 48 & 57 & 51.75 & 25.88 \\
\hline 15 & 14 & 75 & 52 & 56 & 54 & 55 & 54.25 & 27.13 \\
\hline 16 & 15 & 100 & 75 & 79 & 75 & 76 & 76.25 & 38.13 \\
\hline 17 & 16 & 75 & 67 & 60 & 61 & 60 & 62.00 & 31.00 \\
\hline 18 & 17 & 80 & 55 & 65 & 60 & 59 & 59.75 & 29.88 \\
\hline 19 & 18 & 75 & 47 & 42 & 46 & 45 & 45.00 & 22.50 \\
\hline 20 & 19 & 90 & 60 & 58 & 58 & 62 & 59.50 & 29.75 \\
\hline 21 & 20 & 85 & 64 & 52 & 58 & 53 & 56.75 & 28.38 \\
\hline 22 & 21 & 100 & 67 & 67 & 63 & 70 & 66.75 & 33.38 \\
\hline
\end{tabular}

cps $=$ Counts per Second; Av. $=$ Average; Background Count $=14.63 \mathrm{cp}$

Table 4. Gamma Radiation Reading in counts per second (cps); Traverse Ore-Ijebuode, interval distance $=1 \mathrm{~km}$

\begin{tabular}{|l|l|l|l|l|l|l|l|l|}
\hline \multicolumn{4}{|c|}{ Scintillation counter(cps) } & \multicolumn{3}{c|}{ Spectrometer(cps) } & \\
\hline Station No & Distance $(\mathrm{km})$ & Total count/sec(cps) & 1 & 2 & 3 & 4 & Av.count per 2sec \\
\hline 1 & 0 & 100 & 57 & 58 & 54 & 55 & 56 \\
\hline 2 & 1 & 45 & 41 & 48 & 41 & 52 & 44.25 \\
\hline 3 & 2 & 35 & 14 & 15 & 15 & 20 & 16 \\
\hline 4 & 3 & 35 & 24 & 24 & 22 & 22 & 23 \\
\hline 5 & 4 & 30 & 21 & 19 & 25 & 22 & 21.75 \\
\hline 6 & 5 & 40 & 35 & 30 & 27 & 30 & 30.50 \\
\hline 7 & 6 & 35 & 21 & 25 & 22 & 21 & 22.25 \\
\hline 8 & 7 & 50 & 19 & 20 & 21 & 18 & 19.50 \\
\hline 9 & 8 & 65 & 36 & 37 & 39 & 35 & 36.75 \\
\hline 10 & 55 & 39 & 44 & 36 & 36 & 38.75 \\
\hline 11 & 9 & 55 & 27 & 21 & 28 & 25 & 25.25 \\
\hline 12 & 10 & 75 & 36 & 34 & 30 & 37 & 34.25 \\
\hline 13 & 11 & 65 & 38 & 40 & 42 & 39 & 39.75 \\
\hline 14 & 12 & 52 & 41 & 49 & 52 & 48.50 \\
\hline
\end{tabular}

cps $=$ Counts per Second; Av. $=$ Average; Background count $=16 \mathrm{cps}$ 


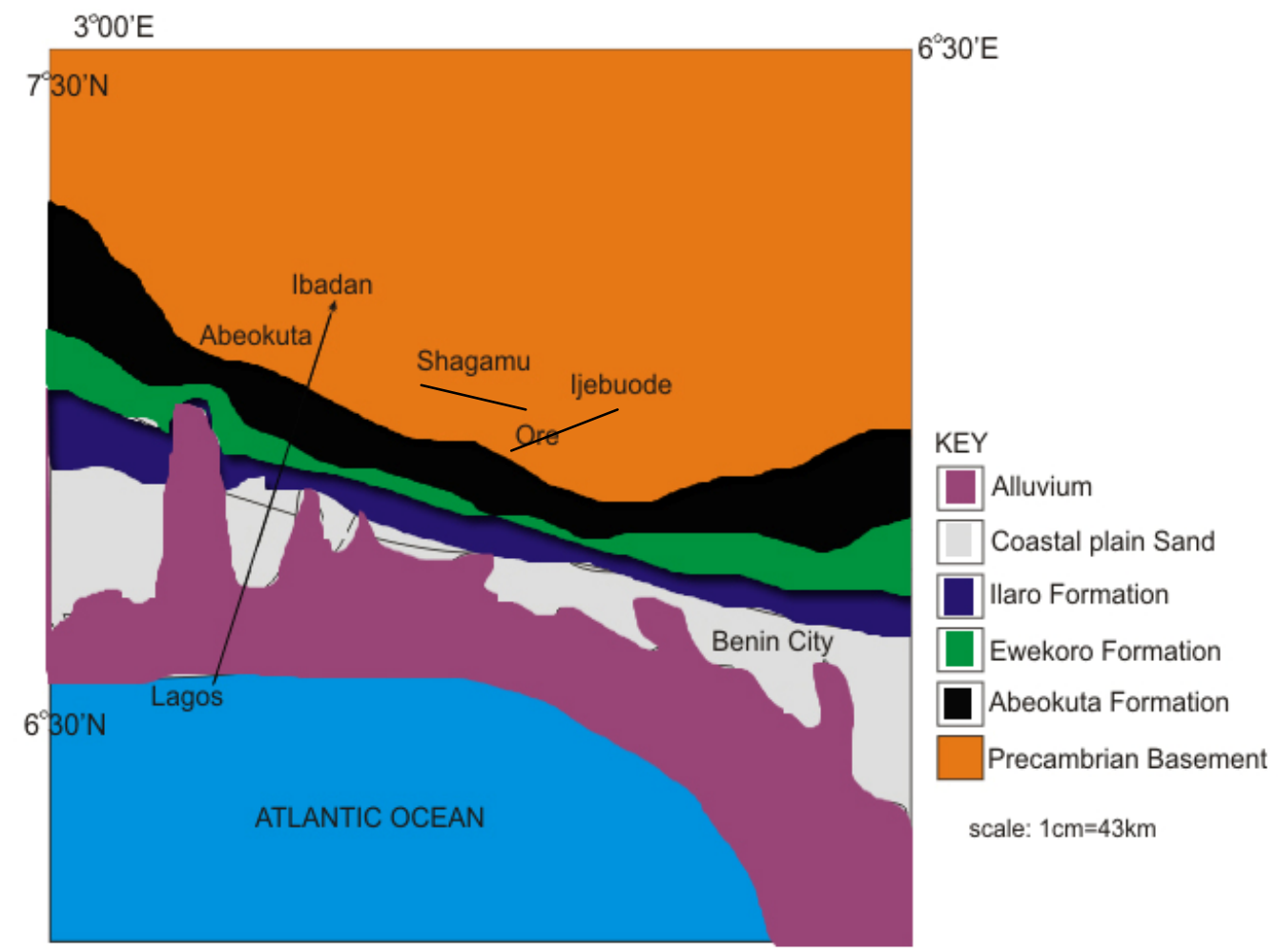

Figure 1. Geology map of the study area (Modified from Bankole, et. al., 2006)

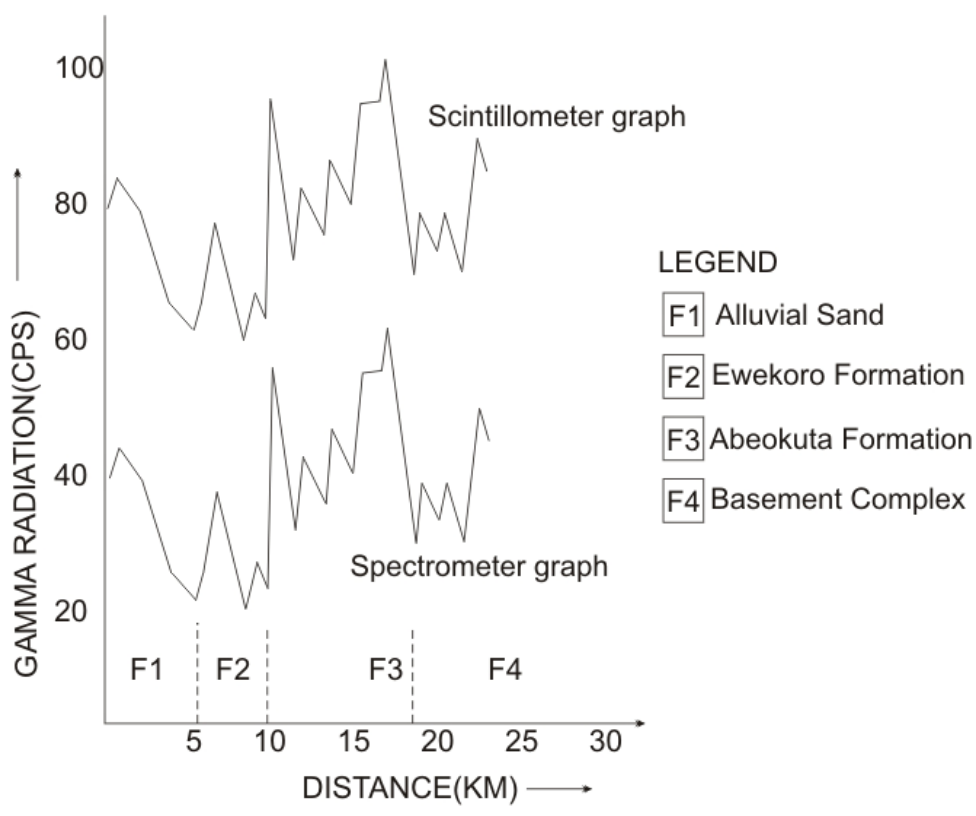

Figure 2. Plot of gamma radiation (cps) against distance $(\mathrm{km})$

Traverse: Ibadan-Lagos Expressway (Interval Distance $=1 \mathrm{~km})$ 


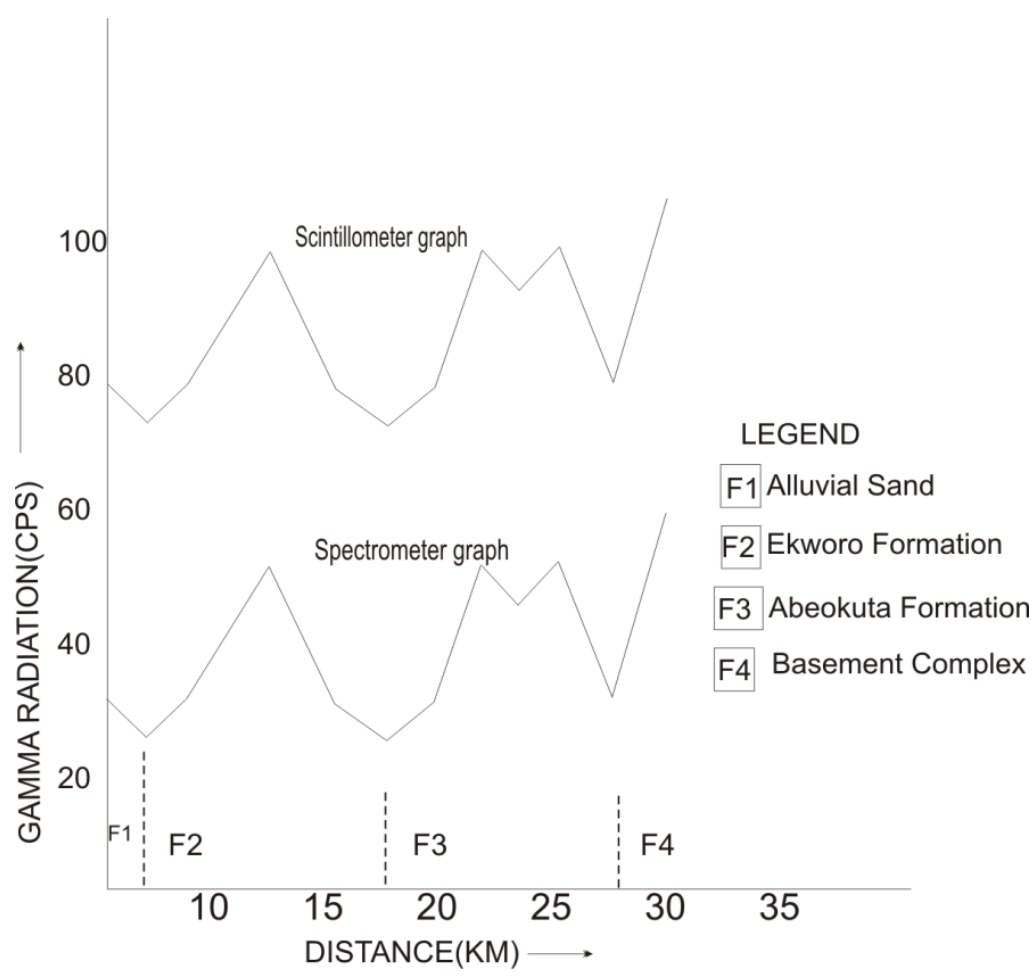

Figure 3. Plot of gamma radiation (cps) against distance $(\mathrm{km})$

Traverse: Shagamu-Ijebuode road $($ Interval Distance $=1 \mathrm{~km})$

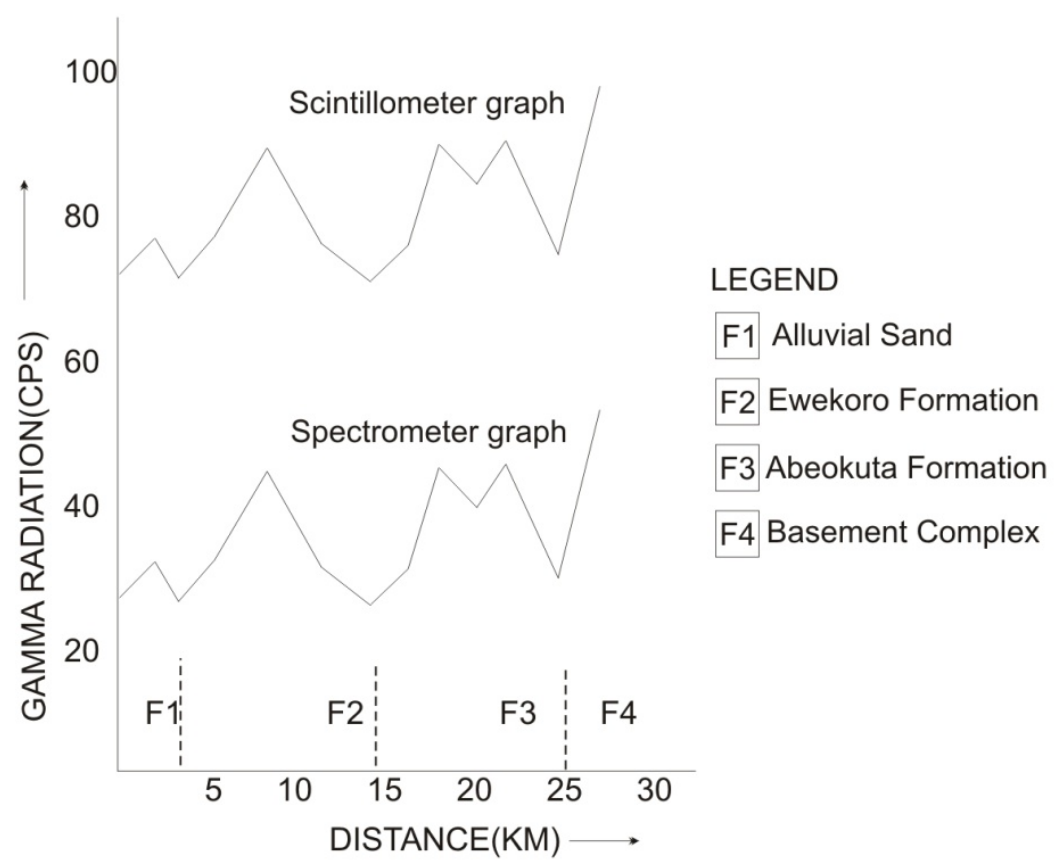

Figure 4. Plot of gamma radiation (cps) against distance $(\mathrm{km})$

Traverse Ore-Ijebuode, interval distance $=1 \mathrm{~km}$ 